Publisher: African Networks on Ethnomedicines

Web page: /http://journals.sfu.ca/africanem/index.php/ajtcam/index

http://dx.doi.org/10.4314/ajtcam.v9i4.9

\title{
GARCINIA KOLA SEEDS: IS THE AQUEOUS EXTRACT A TRUE APHRODISIAC IN MALE WISTAR RATS?
}

*Yakubu, M. T. and Quadri, A. L.

\author{
Phytomedicine, Toxicology, Reproductive and Developmental Biochemistry Research Laboratory, \\ Department of Biochemistry, University of Ilorin, \\ PMB 1515, Ilorin, Nigeria. \\ *Email: tomuyak@yahoo.com; tomuyak@gmail.com
}

\begin{abstract}
The age long acclaimed aphrodisiac potentials of Garcinia kola seeds in some parts of Western Nigeria has not been substantiated with scientific evidence. In this study, we have decided to evaluate the effect of aqueous seed extract of $G$. kola at the doses of 25, 50 and $100 \mathrm{mg} / \mathrm{kg}$ body weight on sexual behaviour of male rats. Male rats weighing $215.00 \pm 18.58$ $\mathrm{g}$ were randomized completely into four groups (A-D) of six animals each. Animals in group A received, orally, $0.5 \mathrm{ml}$ of distilled water only while those in groups B, C and D received same volume containing 25, 50 and $100 \mathrm{mg} / \mathrm{kg}$ body weight of the seed extract respectively. Frequencies of mount (MF), intromission (IF), genital toilet (GTF) and ejaculation (EF) as well as latencies of mount (ML), intromission (IL) and ejaculation (EL) were evaluated following the pairing of male rats (1:1) with non-oestrous female rats. The parameters were monitored for the first (15-30 min), second (75-90 min) and third (180$195 \mathrm{~min}$ ) observatory periods. The levels of testosterone, luteinizing (LH) and follicle stimulating hormones (FSH) were also determined. Phytochemical screening of the extract revealed the presence of saponins (2.78\%), cardiac glycosides $(0.26 \%)$, cardenolides and dienolides (0.24\%), flavonoids (1.28\%) and steroids (1.14\%). The 25 and $100 \mathrm{mg} / \mathrm{kg}$ body weight increased $(\mathrm{P}<0.05)$ the MF whereas the ML was decreased by all the doses of the extract. MF and ML were not altered during the second observatory period whereas the $50 \mathrm{mg} / \mathrm{kg}$ body weight increased these parameters during the third observatory period. Other sexual behaviour parameters as well as serum testosterone, FSH and LH were not significantly altered throughout the observatory periods. Overall, the results revealed that G. kola seeds did not have sex enhancing potential as claimed. Therefore, the acclaimed pro sexual effect of Garcinia kola seeds is scientifically untrue. This study has refuted the claim that one of the rationales for consuming the seeds by the aged population of Nigeria is to enhance sexual invigoration in males.
\end{abstract}

Keywords: Garcinia kola seeds, Guttifera, aphrodisiac, sexual behaviour

\section{Introduction}

Traditional herbs have been reported to have contributed to revolutionary breakthrough in the management of sexual inadequacies and have become known worldwide as an "instant" treatment (Adimoelja, 2000). These botanicals include Terminalia cattapa seeds (almond fruit), leaves, roots and fruits of Musa parasidiaca L (plantain) as well as Fadogia agrestis (Ratnasooriya and Dharmasiri, 2000; Yakubu et al., 2005). In Nigeria, one plant that has been acclaimed to have sex enhancing potential is Garcinia kola seeds. This claim was further buttressed that it may be the rationale behind its consumption by the elderly since sexual inadequacies is most common in the aged population.

Garcinia kola Heckel (family-Guttifera) also known as bitter kola, false kola and male kola (English), orogbo (Yoruba-Western Nigeria), cida goro (Hausa-Northern Nigeria), Aku ilu or Ugugolu (Igbo-Eastern Nigeria), Efiari (Efik), and Igoligo (Idoma-Middle Belt) is an evergreen, dicotyledonous plant found in moist forest, riverine and swampy areas. It grows to a medium sized tree of about 12-15 m high and a girth of $1.80 \mathrm{~m}$. It occurs naturally in Sierra Leone, Nigeria and Angola.

The seeds have a bitter taste; hence, it is called bitter kola in Nigeria. As a result of this bitter taste, the seeds have been consumed as a stimulant (Atawodi et al., 1995). The seeds have also been used in the treatment of liver disorders and diarrhoea (Blaide, 1991), diabetes, bronchitis and throat infections (Orie and Ekon, 1993; Tita et al., 2001), and as a natural antimicrobial (Ositelu et al., 2004). G. kola has also been reported to posses some hepatoprotective and aphrodisiac properties (Akintonwa and Essein, 1990; Ajibola and Satake, 1992). It has also been reported to be effective in the treatment of dermatological disorders associated with melanin pigmentation (Okunji et al., 2007).

Despite the acclaimed use of $G$. kola seeds as sex invigorator in some parts of Nigeria, there seems not to be any information in the open scientific literature on this claim. Therefore, this study was aimed at evaluating this claim with a view to substantiating or refuting it. Several authors have assessed the aphrodisiac potentials of many plants using physical and biochemical parameters such as mount frequency (MF), intromission frequency (IF), genital toileting frequency (GTF), ejaculation frequency (EF) mount latency (ML), intromission latency (IL) and ejaculation latency (EL), testosterone, follicle stimulating hormone (FSH) and luteinizng hormone (LH) (Ratnasooriya and Dharmasiri, 2000; Tajuddin et al., 2004; Zamble et al., 2008; Yakubu and Afolayan, 2009), hence, the use of these parameters in this study. 
Publisher: African Networks on Ethnomedicines

Web page: /http://journals.sfu.ca/africanem/index.php/ajtcam/index

http://dx.doi.org/10.4314/ajtcam.v9i4.9

\section{Materials and methods \\ Plant material and authentication}

G. kola seeds purchased from herbsellers at Agor Market, Ilorin, Nigeria, was authenticated by Mr. Michael Onadeji of the Forestry Research Institute of Nigeria, Ibadan, Nigeria. A voucher number (F.H.I. 10847) was deposited at the herbarium of the Institute.

\section{Assay kits}

Testosterone assay kit was a product of Diagnostic Automation Inc., Calabasas, USA, while those of LH and FSH were products of Syntron Bioresearch, Inc., Carlsbad, USA.

\section{Other reagents}

All other reagents used were of analytical grades and were prepared in volumetric flasks using glass-distilled water.

\section{Experimental Animals}

Healthy, sexually matured, male albino rats (Rattus norvegicus) weighing $215.00 \pm 18.58 \mathrm{~g}$ and female albino rats weighing 195. $90 \pm 10.97 \mathrm{~g}$ were obtained from the Animal Holding Unit of the Department of Biochemistry, University of Ilorin, Ilorin, Nigeria. The animals were housed in aluminium cages placed in a well-ventilated house with optimum conditions (temperature: $22 \pm 3^{0} \mathrm{C}$; photoperiod: $12 \mathrm{~h}$ natural light and $12 \mathrm{~h}$ dark; humidity: 40-45\%) with free access to rat pellets (Bendel Feeds and Flour Mills Ltd, Ewu, Nigeria) and tap water. The animals were handled humanely according to the guidelines of National Institute for Health, USA (NIH, 1985).

\section{Preparation of extract}

G. kola seeds were peeled, sliced into thin pieces and oven-dried at $40^{\circ} \mathrm{C}$ for $72 \mathrm{~h}$ to a constant weight using Uniscope Laboratory Oven, (model- SM9053, Surgifriend Medicals, England). The materials were then pulverized with an electric blender (Crown Star Blender-model CS- 242B, Trident (H.K) Ltd, China). A portion of the powder (300 g) was extracted in $1000 \mathrm{ml}$ of distilled water for $48 \mathrm{~h}$ at room temperature with constant shaking (SO1 orbital shaker, Stuart Scientific, Stone, UK). The extract was then filtered with Whatman No. 1 filter paper. The filtrate was concentrated on steam bath to give a yield of $16.42 \mathrm{~g}$ of the residue. This was later reconstituted in distilled water to give the required doses of 25 , 50 and $100 \mathrm{mg} / \mathrm{kg}$ body weight used in this study.

\section{Phytochemical screening}

A portion of the extract ( $1 \% \mathrm{w} / \mathrm{v})$ was subjected to standard chemical tests as described for alkaloid (Harborne, 1984), steroids, anthraquinones, cardenolides and dienolides (Trease and Evans, 1989), phenolics and flavonoids (Awe and Sodipo, 2001), cardiac glycoside and saponins (Sofowora, 1993), tannins, phlobatannins and triterpenes (Odebiyi and Sofowora, 1978). The detected phytochemicals were quantitatively determined for saponins (Obadoni and Ochuko, 2001), flavonoids (Boham and Kocipai-Abyazan, 1974), steroids, cardiac glycosides, cardenolides and dienolides (El-Olemy et al., 1994).

\section{Animal grouping, extract administration and monitoring of sexual behaviour indices}

The animals were randomly grouped into four (A-D) of six rats each. Animals in groups A, which served as the control, received $0.5 \mathrm{ml}$ of distilled water while those in groups B, C and D were treated like the control except they received same volume containing 25, 50 and $100 \mathrm{mg} / \mathrm{kg}$ body weight of the extract. All administrations were done orally using metal oropharyngeal cannula. Immediately after their respective administration $(T=0)$, the animals were allowed an acclimatization period of $15 \mathrm{~min}$. A non-oestrous female was introduced into the plastic cage $(\mathrm{T}=15 \mathrm{~min})$, in ratio $1: 1$ and sexual behavioural parameters were then monitored for observatory periods of first (15-30 min), second (75-90 min), and third (180-195 min) after administering the extract (Ramachandran et al., 2004; Zamble et al., 2008). Adopting the standard procedures described by Amin et al. (1996) and Agmo (1997), the male sexual behaviour indices monitored during the three observatory periods included: MF (the number of mounts from the time of introduction of the female until ejaculation), IF, (the number of intromissions from the time of introduction of the female until ejaculation), GTF (number of times the male rat cleaned up the tip of the copulatory organ), EF (the number of times semen was ejected from the male copulatory organ), ML (the time interval between the introduction of the female and the first mount by the male), IL (the time interval between the introduction of the female and the first intromission by the male) and EL (the time interval between the first intromission and ejaculation).

\section{Preparation of serum}

Immediately after the termination of the third observatory period, male rats were anaesthetized in a jar containing 
Publisher: African Networks on Ethnomedicines

Web page: /http://journals.sfu.ca/africanem/index.php/ajtcam/index

http://dx.doi.org/10.4314/ajtcam.v9i4.9

cotton wool soaked in ether fume. The neck areas were quickly cleared of fur and skin to expose the jugular veins. The jugular veins were slightly displaced from the neck region (to prevent contamination of the blood with interstitial fluid) and then cut with a sharp sterile blade. The rats were held head downwards and allowed to bleed into a clean, dry centrifuge tube, which were left at room temperature for $10 \mathrm{~min}$ to clot. The tubes were later centrifuged at $503 \mathrm{~g}$ x 10 min using Uniscope Laboratory Centrifuge (model SM800B, Surgifriend Medicals, England). The sera were thereafter aspirated using a Pasteur pipette into clean, dry, sample bottles and were used within $12 \mathrm{~h}$ of preparation for the hormonal assay.

\section{Hormonal assay}

The hormones were assayed in the serum of the animals following the procedure outlined in the manufacturers' instruction manual as described for testosterone (Chen et al., 1991), FSH (Kapen et al., 1973) and LH (Uotila et al., 1981).

\section{Statistical analysis}

Data were mean \pm SEM of six replicates. They were analyzed for statistical significance using Duncan Multiple Range Test and complemented with Student's t-test. Differences were considered statistically significant at $\mathrm{P}<0.05$ (Mahajan, 1997).

\section{Results}

Aqueous extract of G. kola seeds gave positive tests to cardiac glycosides, flavonoids, steroids, saponins, cardenolides and dienolides while tannins, anthraquinones, phenolics, phlobatannins and triterpenes were not detected (Table 1). Quantitatively, the extract was found to have saponins in highest concentration followed by flavonoids and steroids while cardiac glycosides, cardenolides and dienolides were weakly present (Table 1).

Among all the physical indices of sexual behaviour monitored in male rats, the extract only produced significant effects on the MF and ML. For instance, the extract at 25 and $100 \mathrm{mg} / \mathrm{kg}$ body weight increased the MF during the first observatory period (Table 2), whereas it was all the doses that significantly reduced the ML during the same period (Table 3). In contrast, no effect was produced on the MF and ML by the extract during the second observatory period. This incidence of null effect on the MF and ML by the extract was extended to the third observatory period in all the treatment groups except those administered with the $50 \mathrm{mg} / \mathrm{kg}$ body weight of the extract where the MF and ML increased significantly (Tables 2 and 3).

Furthermore, all the doses of the extract did not produce any effect on the IF, IL, EF, EL and GTF throughout the exposure period (nil values not shown). Again, the levels of FSH, LH and testosterone in the serum of the animals treated with the extract were not significantly altered at the end of the observatory period when compared with their respective control values (Table 4).

\section{Discussion}

This study has refuted the acclaimed use of G. kola seeds as an aphrodisiac in some parts of Western Nigeria. Male rats in the presence of non-oestrous female did not improve their sexual performance when orally administered with varying doses of aqueous seed extract of $G$. kola. Observation at each experimental period in this study revealed that sexual function in male rats were not enhanced, more so, when some indices of sexual performance such as IF, IL, EF, EL and GTF had no value.

Table 1: Phytochemical constituents of aqueous extract of Garcinia kola seeds

\begin{tabular}{ll}
\hline Phytochemicals & Concentration (\%) \\
\hline Cardiac glycosides & $0.26 \pm 0.02$ \\
Tannins & Not Detected \\
Anthraquinones & Not detected \\
Phenolics & Not Detected \\
Flavonoids & $1.28 \pm 0.01$ \\
Steroids & $1.14 \pm 0.05$ \\
Saponins & $2.78 \pm 0.03$ \\
Frothing time & $4 \mathrm{~h} 20$ min \\
Frothing height & $4.85 \mathrm{~cm}$ \\
Alkaloids & Not Detected \\
Cardenolides and dienolides & $0.24 \pm 0.03$ \\
Phlobatannins & Not Detected \\
Triterpenes & Not Detected \\
\hline
\end{tabular}

Results are mean \pm SEM of three replicates 
Publisher: African Networks on Ethnomedicines

Web page: /http://journals.sfu.ca/africanem/index.php/ajtcam/index http://dx.doi.org/10.4314/ajtcam.v9i4.9

According to Singh and Mukherjee (1998), aphrodisiac is any substance that (a) stimulate the production of semen (b) improve and purify the quality of semen (c) help sexually and in ejaculation (d) delay the time of ejaculation and (e) arouse sexual desire. Therefore, the aqueous extract of G. kola seeds may not be considered as a sex enhancer and or sexual invigorator since it did not satisfy the aforementioned properties most especially, sexual arousal, prolonged ejaculation latency and many fold increase in mounting during the observatory periods. Furthermore, the significantly enhanced MF and ML, which are useful indices of sexual vigour, libido and arousability (Tajuddin et al., 2004; Mbongue et al., 2005), in the first observatory period, does not necessarily qualify the seed extract as an aphrodisiac because the indices were not sustained beyond this period. All these, coupled with the nil values of IF, GTF, EF, IL and EL obtained in this study further suggests that sexual appetitive behaviour was not enhanced by the extract (Yakubu and Afolayan, 2009).

Table 2: Effect of administration of aqueous seed extract of $G$. kola on mount frequency of male rats

\begin{tabular}{|c|c|c|c|}
\hline \multirow[b]{2}{*}{ Doses } & \multicolumn{2}{|c|}{ Observatory Periods (min) } & \multirow[b]{2}{*}{ Third (180-195) } \\
\hline & First (15-30) & Second (75-90) & \\
\hline $\begin{array}{l}\text { Distilled water }(2.33 \mathrm{ml} / \mathrm{kg} \text { body } \\
\text { weight }\end{array}$ & $0.33 \pm 0.12^{\mathrm{a}}$ & $0.00 \pm 0.00^{\mathrm{a}}$ & $0.00 \pm 0.00^{\mathrm{a}}$ \\
\hline $\begin{array}{l}25 \mathrm{mg} / \mathrm{kg} \text { body weight of the } \\
\text { extract }\end{array}$ & $1.67 \pm 0.37^{\mathrm{b}}$ & $0.00 \pm 0.00^{\mathrm{a}}$ & $0.00 \pm 0.00^{\mathrm{a}}$ \\
\hline $\begin{array}{l}50 \mathrm{mg} / \mathrm{kg} \text { body weight of the } \\
\text { extract }\end{array}$ & $0.33 \pm 0.08^{\mathrm{a}}$ & $0.00 \pm 0.00^{\mathrm{a}}$ & $8.06 \pm 2.87^{b}$ \\
\hline $\begin{array}{l}100 \mathrm{mg} / \mathrm{kg} \text { body weight of the } \\
\text { extract }\end{array}$ & $0.67 \pm 0.03^{\mathrm{c}}$ & $0.00 \pm 0.00^{\mathrm{a}}$ & $0.00 \pm 0.00^{\mathrm{a}}$ \\
\hline
\end{tabular}

Values are mean \pm SEM of six replicates

Values carrying superscript different from the control are significantly different $(\mathrm{P}<0.05)$.

Table 3: Effect of administration of aqueous seed extract of $G$. kola on mount latency of male rats

\begin{tabular}{|c|c|c|c|}
\hline \multirow[b]{2}{*}{ Doses } & \multicolumn{2}{|c|}{ Observatory Periods (min) } & \multirow[b]{2}{*}{ Third (180-195) } \\
\hline & First (15-30) & Second (75-90) & \\
\hline $\begin{array}{l}\text { Distilled water }(2.33 \mathrm{ml} / \mathrm{kg} \text { body } \\
\text { weight }\end{array}$ & $4.20 \pm 1.29^{\mathrm{a}}$ & $0.00 \pm 0.00^{\mathrm{a}}$ & $0.00 \pm 0.00^{\mathrm{a}}$ \\
\hline $\begin{array}{l}25 \mathrm{mg} / \mathrm{kg} \text { body weight of the } \\
\text { extract }\end{array}$ & $1.47 \pm 0.26^{\mathrm{b}}$ & $0.00 \pm 0.00^{\mathrm{a}}$ & $0.00 \pm 0.00^{\mathrm{a}}$ \\
\hline $\begin{array}{l}50 \mathrm{mg} / \mathrm{kg} \text { body weight of the } \\
\text { extract }\end{array}$ & $1.43 \pm 0.26^{\mathrm{b}}$ & $0.00 \pm 0.00^{\mathrm{a}}$ & $2.24 \pm 0.36^{\mathrm{b}}$ \\
\hline $\begin{array}{l}100 \mathrm{mg} / \mathrm{kg} \text { body weight of the } \\
\text { extract }\end{array}$ & $0.34 \pm 0.07^{\mathrm{C}}$ & $0.00 \pm 0.00^{\mathrm{a}}$ & $0.00 \pm 0.00^{\mathrm{a}}$ \\
\hline
\end{tabular}

Values are mean \pm SEM of six replicates

Values carrying superscript different from the control are significantly different $(\mathrm{P}<0.05)$.

Table 4: Effect of administration of aqueous seed extract of $G$. kola on some reproductive hormones of male rats

\begin{tabular}{|c|c|c|c|}
\hline \multirow[b]{2}{*}{ Doses } & \multicolumn{2}{|c|}{ Observatory Periods (min) } & \multirow[b]{2}{*}{ Testosterone (ng/ml) } \\
\hline & $\begin{array}{l}\text { Follicle stimulating } \\
\text { hormone (mIU/L) }\end{array}$ & $\begin{array}{l}\text { Luteinizing hormone } \\
\text { (mIU/L) }\end{array}$ & \\
\hline $\begin{array}{l}\text { Distilled water }(2.33 \mathrm{ml} / \mathrm{kg} \text { body } \\
\text { weight }\end{array}$ & $2.35 \pm 0.15^{\mathrm{a}}$ & $1.00 \pm 0.11^{\mathrm{a}}$ & $5.15 \pm 0.25^{\mathrm{a}}$ \\
\hline $\begin{array}{l}25 \mathrm{mg} / \mathrm{kg} \text { body weight of the } \\
\text { extract }\end{array}$ & $2.29 \pm 0.22^{\mathrm{a}}$ & $1.03 \pm 0.14^{\mathrm{a}}$ & $5.15 \pm 0.15^{\mathrm{a}}$ \\
\hline $\begin{array}{l}50 \mathrm{mg} / \mathrm{kg} \text { body weight of the } \\
\text { extract }\end{array}$ & $2.30 \pm 0.12^{\mathrm{a}}$ & $1.05 \pm 0.10^{\mathrm{a}}$ & $5.05 \pm 0.26^{\mathrm{a}}$ \\
\hline $\begin{array}{l}100 \mathrm{mg} / \mathrm{kg} \text { body weight of the } \\
\text { extract }\end{array}$ & $2.30 \pm 0.19^{\mathrm{a}}$ & $1.01 \pm 0.12^{\mathrm{a}}$ & $5.16 \pm 0.13^{\mathrm{a}}$ \\
\hline
\end{tabular}

Values are mean \pm SEM of six replicates

Values carrying the same superscript as the control are not significantly different $(\mathrm{P}>0.05)$.

Elevated level of testosterone has been associated with a moderate but significant increase in sexual desire and penile function (Gauthaman et al., 2002). Clinical data on testosterone also suggest that a slightly increased level of testosterone in adult males results in an enhanced sexual desire and arousability (Thakur and Dixit, 2007). The level of 
Publisher: African Networks on Ethnomedicines

Web page: /http://journals.sfu.ca/africanem/index.php/ajtcam/index

http://dx.doi.org/10.4314/ajtcam.v9i4.9

testosterone has been reported to be related to LH and FSH such that increase in the levels of the gonadotropins results in corresponding increase in testosterone (Andersen and Tufik , 2006). Therefore, it is not surprising that these hormones which have specific roles to play in sexual activity of animals were not significantly altered. Such a lack of significant change in the levels of the reproductive hormones in this study is an indication that GnRH-LH signalling was not affected. This further supports the non-enhancement of the sexual appetitive behaviour of the animals and also explain the lack of effect on IF, GTF, EF, IL and EL.

Several phytochemicals have been implicated in enhancing sexual function in male rats. For example, saponins in Fadogia agrestis (Schweinf. Ex Hiern) and Tribulus terrestris (Linn.) as well as alkaloids in Pausinystalia yohimbe (K. Schum) and Microdesmis keayana (J. Leonard) have been shown to be responsible for aphrodisiac activity (Ernst and Pittler, 1998; Gauthaman et al., 2002; Yakubu et al., 2005; Zamble et al., 2008). Similarly, prosexual stimulatory property of Mondia whitei Hook (Skeels) has also been attributed to its steroid and triterpene contents (Drewes et al., 2003). These bioactive agents exhibit aphrodisiac activity either by increasing the biosynthesis and secretion of androgens or act directly on the central nervous system to modulate the action of neurotransmitters and gonadal tissues in animals. Specifically, saponins enhance androgen production (Gauthaman et al., 2002) whereas alkaloids may increase the dilation of blood vessels in the sexual organs (Perbot, 1982), or increase nitric oxide that plays a key role in central erection and central sexual stimulation (Zamble et al., 2008). Interestingly, some of these phytochemicals such as saponins and steroids were also detected in the seed extract in this study; it is possible that the extract lacked the specific type. For instance, steroidal saponins have been implicated to play a role in enhancing sexual behaviour by either binding to hormone receptors, which may result in conformational change that will enhance the physiological function of the hormones or bind to enzymes that are involved in the synthesis of such hormones and thus enhance its production (Gauthaman and Adaikan, 2008), whereas none of such has ever been reported for the second class of saponins, the triterpenoid saponins.

This study has thus revealed that aqueous seed extract of G. kola did not possess aphrodisiac activity as claimed and may not explain the consumption of the seeds mainly by the aged. Furthermore, the results taken together discourage the continued claim or assumption of Garcinia kola seeds as an aphrodisiac.

\section{References}

1. Adimoelja, A. (2000) Phytochemicals and the breakthrough of traditional herbs in the management of sexual dysfunction. Int. J. Androl. 23 (Suppl 2): 82-84.

2. $\quad$ Agmo, A. (1997). Male rat sexual behaviour. Brain Res. Protocol 1: 203-209.

3. Ajibola, A. O. and Satake, M. (1992). Contributions to the phytochemistry of medicinal plants growing in Nigeria as reported in the 1979-1990 literature - A preview. Afr. J. Pharm. Sci. 22:172-201.

4. Akintonwa, A. and Essein, A. R. (1990). Protective effects of Garcinia kola seed against paracetamol - induced hepatoxicity in rats. J. Ethnopharmacol. 29:207-211.

5. Andersen, M. L. and Tufik, S. (2006). Does male sexual behavior require progesterone? Brain Res. Rev. 51:136143.

6. Amin, K. M. Y., Khan, M. N., Rahman, S. Z. and Khan, N. A. (1996) Sexual function improving effect of Mucuna pruriens in sexually normal male rats. Fitoterapia 67:53-58.

7. Atawodi, S., Mende, P., Pfundstein, B., Preussmann, R. and Spiegelhalier, B (1995). Nitrosatable amines and nitrosomide formation in natural stimulants, Cola acuminata, Cola nitida and Garcinia kola. Food Chem. Toxicol. 33:625-630.

8. Awe, I. S. and Sodipo, O. A. (2001) Purification of saponins of root of Bhlighia sapida Koenig-Holl. Nig. J. Biochem. \& Mol. Biol. (Proceedings Supplement) 16: 201s-204s.

9. Blaide, V. D. (1991). Pharmacology effects of Chronic Ingestion of Garcinia kola seeds in the Rats. Phtother. Res. 4:39-41.

10. Boham, B. A, and Kocipai-Abyazan, R (1974). Flavonoids and condensed tannins from leaves of Hawaiian vaccinium vaticulatum and V. calycinium. Pacific Sci. 48: 458-463.

11. Chen, A., Bookstein, J. J. and Meldrum, D. R. (1991). Diagnosis of a testosterone-secreting adrenal adenoma by selective venous catheterization. Fertil. Steril. 55: 1202-1203.

12. Drewes, S. E., George, J. and Khan, F. (2003). Recent findings on natural products with erectile-dysfunction activity. Phytochemistry 62: 1019-1025.

13. El-Olemy, M. M., Al-Muhtadi, F. J. and Afifi, A. A. (1994). 'Experimental Phytochemistry: A Laboratory Manual' (El-Olemy, M. M.; Al-Muhtadi, F. J. and Afifi, A. A. eds.), pp. 3-137. King Saud University Press, Riyadh, Saudi Arabia.

14. Ernst, E. and Pittler, M. H. (1998) Yohimbine for erectile dysfunction: a systematic review and meta-analysis of randomized clinical trials. J. Urol. 159: 433-436.

15. Gauthaman, K. and Adaikan, P. G. (2008): The hormonal effects of Tribulus terrestris and its role in the management of male erectile dysfunction-an evaluation using primates, rabbits and rats. Phytomed. 15: 44-54.

16. Gauthaman, K., Adaikan, P. G. and Prasada, R. N. V. (2002). Aphrodisiac properties of Tribulus terrestris extract (Protodioscin) in normal and castrated rats. Life Sci. 71: 1385-1396.

17. Harborne, J. B. (1984). In: ‘A Guide to Modern Techniques of Plant Analysis’ (Harborne, J. B. ed.), pp. 192. Chapman and Hall, London.

18. Kapen, S., Boyar, R., Hellman, L. and Weitzman, E. D. (1973). Episodic release of luteinizing hormone at midmenstrual cycle in normal adult women. J. Clin. Endocrine Metab. 36: 724-729.

19. Mahajan, B. K. (1997). In: 'Methods in Biostatistics for Medical and Research Workers' (Mahajan, B. K. ed.), pp. 130-155, JAYPEE Brothers Medical Publishers, New Delhi, India. 
Publisher: African Networks on Ethnomedicines

Web page: /http://journals.sfu.ca/africanem/index.php/ajtcam/index

http://dx.doi.org/10.4314/ajtcam.v9i4.9

20. Mbongue, F. G. Y., Kamtchouing, P., Essame, O. J. L., Yewah, P. M., Dimo, T. and Lontsi, D. (2005). Effect of the aqueous extract of dry fruits of Piper guineense on the reproductive function of adult male rats. Indian J. Pharmacol. 37: 30-32.

21. National Institute of Health (1985). NIH Publications, National Research Council, Washington DC, USA, No. 83127.

22. Obadoni, B. O. and Ochuko, P. O. (2001) Phytochemical studies and comparative efficacy of the crude extracts of some homeostatic plants in Edo and Delta States of Nigeria. Global J. Pure \& Appl. Sci. 8: 203-208.

23. Odebiyi, A. and Sofowora, A. E. (1978). Phytochemical screening of Nigerian medicinal plants. Part III. Lloydia 41: 234-246.

24. Okunji, C., Komarnytsky, S., Feara, G., Pouler, A., Ribnicky, D, M., Ayrwadie, P. I., Ito, Y., Raskin, I. (2007). Preparative isolation and identification of tyrosinase inhibitors from the seeds of Garcinia kola by high-speed countercurrent chromatography. J. Chromatography A. 1151:45-50.

25. Orie, N. N. and Ekon, E. U. (1993). The Bronchodilator effects of Garcinia kola. Afr. J. Pharm. Sci. 22:172-201.

26. Ositelu, A. O., Adefule, A. K., Oosa, B. O., Onyenefa, P. C. (2004) Antifungal activity of Garcinia kola nut extract as an ocular bacterial isolates in Lagos. Nig., Qt. J. Hosp. Med. 14:112-114.

27. Perbot, T. (1982). In: 'Chemical and Biological Perspectives’ (Pelletier, S. W. ed.), pp. 79-85. Kyodoshing Loog Printing Ind. Ltd., Singapore.

28. Ramachandra, S., Sridhar, Y., Kishore Gnana Sam, S., Saravanan, M., Thomas Leonard, J., Anbalagan, N., Sridhar, S.K., (2004). Aphrodisiac activity of Butea frondosa Koen. ex. Roxb. extract in male rats. Phytomed. 11: 165-168.

29. Ratnasooriya, W. D. and Dharmasiri, M. G. (2000). Effects of Terminalia catappa seeds on sexual behaviour and fertility of male rats. Asian J. Androl. 2:213-219.

30. Singh, G. and Mukherjee, T. (1998). Herbal Aphrodisiacs: Indian Drugs 35: 175-182.

31. Sofowora, A. (1993). In: 'Medicinal Plants and Traditional Medicine in Africa’ (Sofowora, A. ed.), pp. 134-156, Spectrum Books Limited (Publisher), Ibadan, Nigeria.

32. Tajuddin, A. S., Latif, A. and Qasmi, I. A. (2004) Effect of 50\% ethanolic extract of Syzygium aromaticum (L) Merr. \& Perry. (Clove) on sexual behaviour of normal male rats. BMC Compl. \& Altern. Med. 4: 17-24.

33. Thakur, M. and Dixit, V. K. (2007). Effect of some vajikaran herbs on pendiculation activities and in vitro sperm count in male. Sexual Disability 25(4): 203-207.

34. Tita, R. K., Odeigah, P. G., Agomo, P. U., Bassey, E. (2001). Some properties of medicinal plants used by the Igbos in Nigeria In; trials, tracts and traces. (Germany). Edited by Wolfgang Kreis pp 209-210.

35. Trease, G. E. and Evans, W. C. (1989). In: ‘Textbook of Pharmacognosy’ (Trease, G. E. and Evans, W. C. ed.), pp. 19-21, Bailliere-Tindall Ltd., London..

36. Yakubu, M. T. and Afolayan, A. J. (2009). Effect of aqueous extract of Bulbine natalensis (Baker) stem on the sexual behaviour of male rats. Int. J. Androl. 32: 629-636.

37. Yakubu, M. T., Akanji, M. A. and Oladiji, A. T. (2005). Aphrodisiac potentials of aqueous extract of Fadogia agrestis (Schweinf, Ex Heirn) stem in male albino rats. Asian J. Androl. 7:399-404.

38. Uotila, M., Ruoslahti, E. and Engvall, E. (1981). Two-site sandwich enzyme immunoassay with monoclonal antibodies to human alpha-fetoprotein. J. Immunol. Methods 42 (1): 11-15.

39. Zamble, A., Sahpaz, S., Brunet, C. and Baillent, F. (2008). Effect of Microdesmis Keayana roots on sexual behaviour of male rats. Phytomed. 15: 625-629. 